\title{
THE EFFECT OF TRUST AND SATISFACTION AND COHESIVITY ON TEAM EFFECTIVENESS IN THE HUMAN RESOURCES DEVELOPMENT AGENCY OF EAST KALIMANTAN PROVINCE
}

\author{
Rina Kusharyanti ${ }^{1}$, Djoko Setyadi ${ }^{2}$, Irsan Tricahyadinata ${ }^{3}$ \\ ${ }^{123}$ Faculty of Economics and Business Mulawarman University \\ E-mail: rina.russianto@gmail.com, djoko.setyadi@feb.unmul.ac.id, irsan.tricahadinata@feb.unmul.ac.id
}

\begin{abstract}
:
This study aims to determine what factors influence the increased effectiveness of the team at the Human Resources Development Agency of East Kalimantan Province. This study uses a cross-sectional design that is data collection that is conducted one time at a predetermined respondent with data analysis used is the partial least square (PLS) approach. A high level of trust will have a positive effect on the greater team effectiveness, so that at the same time team members will feel satisfaction in working with the group which will then affect the success of the team to achieve group goals. Thus, the more team members who are satisfied with the team, the better the performance of the interdependent team in completing the given task.
\end{abstract}

Keywords: $\quad$ Influence of Trust; Satisfaction; Cohesiveness; Team Effectiveness

\section{Introduction}

The success of an organization to achieve its main goals and objectives is determined based on the success of a team or group in the organization. The formation of a team provides an advantage so that they can obtain varied information, knowledge, skills so as to produce ideas or creativity, Salas, et al., (2015). The concept of teamwork is based on the performance of individuals who work collectively and depend on each other, so that many organizations implement group-based performance systems in order to survive and compete more effectively. Teams are a complex social system that requires interdependence between individuals, DeOrtentiis, et al., (2013).

Group performance through forming a special team to implement a product or service is more effective than working individually. However, to achieve the effectiveness of a team is a challenge for the organization, so according to Fung (2014), there are several specific reasons for developing the concept of team effectiveness, namely first, that team effectiveness will increase the productivity and work morale of team members; second, an effective team will relieve the work of the manager so that it will focus on other jobs; Third, effective teams will work within and between teams so that the entire organization can function effectively

Team trust can bind team members to stay in the team (Team Cohesion), because team members feel the attraction of one another. Without team trust, openness and dependence between team members will not be realized, because building perceptions of trust has a negative impact on the team's ability to maintain group cohesiveness, DeOrtentiis, et al., (2013). Cohesion bonds are formed within the team which facilitate group development and maintenance, thus contributing to increased cohesion.

In increasing the productivity of a team's performance, cohesion is one of the determinants of the performance effectiveness characteristics of the team. Picazo, et al., (2015). Team performance in organizations can be measured through the achievement of a cohesive team success. Team cohesion can reflect the attitude of team members who want to stick together to achieve common goals Picazo et al., (2015). Team members who do not feel cohesion, lack of motivation to be involved in tasks will tend not to participate in contributing to the team, Salas et al., (2015). Fung (2014), explains that the greater the cohesiveness in the team, the more effective team members will need each other. Team cohesiveness is very important in understanding group performance, that is, achieving good performance will strengthen 
International Journal of Economics, Business and Accounting Research (IJEBAR)

Peer Reviewed - International Journal

Vol-4, Issue-3, 2020 (IJEBAR)

E-ISSN: 2614-1280 P-ISSN 2622-4771

https://jurnal.stie-aas.ac.id/index.php/IJEBAR

team cohesion in the group, Bravo, et al., (2018). Thus, that team cohesion has an impact on team effectiveness, Daspit, et al., (2013); Bravo, et al., (2018) and improve team performance in achieving group goals.

In addition, the concept of team satisfaction can be felt by team members, by showing the optimization of team performance to achieve certain goals. DeOrtentiis, et al., (2013), stated that job satisfaction in teams has an important role in the effectiveness of team performance which affects individual motivation to work, members' ability to complete tasks, level of effort, and member satisfaction with their work. Therefore, the satisfaction felt by the team can be a mediation between the perception of team trust on the level of team effectiveness, DeOrtentiis, et al., (2013). The phenomenon that occurs in the civil servant work environment, which is the object of research, has several managerial problems that become obstacles and obstacles faced by employees.

In general, the government does not have a good employee recruitment plan, seen from the large number of civil servants who do not have a clear job description. In addition, the mechanism for recruiting employees by the government is inaccurate, where there is no competency and skill test that matches the job requirements. Next is the inaccurate management of employee governance, which includes the placement, coaching and career development of civil servants. In particular, this phenomenon occurs in relation to HR behavior, such as the mismatch of professional work standards (low employee discipline, low motivation, minimal innovation, and the presence of non-formal groups), unequal rewards or rewards systems, and reward-based work systems. will be motivated if there are rewards, in the form of honorarium or others). The findings of preliminary observations through direct observation and interviews regarding team effectiveness, obtained preliminary information that the weakness of the effectiveness of the team being carried out is the lack of control of members of technical matters applied to operational activities (computerization), limited interaction of team members so that it is less intertwined. Optimal communication as well as the gap between treatment and distribution of team job descriptions for PNS and Non PNS officials that are less or not proportional. Many of the workloads carried out are limited to aborting obligations and rarely reaching the essence of loyalty and worship. preliminary information was obtained that the weaknesses in the effectiveness of the team being run were the lack of control of members over technical matters applied to operational activities (computerization), limited team member interactions resulting in less optimal communication and gaps between treatment and distribution of team job descriptions. accepted for civil servants and non-civil servants who are less or not proportional. Many of the workloads carried out are limited to aborting obligations and rarely reaching the essence of loyalty and worship. preliminary information was obtained that the weaknesses in the effectiveness of the team being run were the lack of control of members over technical matters applied to operational activities (computerization), limited team member interactions resulting in less optimal communication and gaps between treatment and distribution of team job descriptions. accepted for civil servants and non-civil servants who are less or not proportional. Many of the workloads carried out are limited to aborting obligations and rarely reaching the essence of loyalty and worship. Limited interaction of team members so that there is less optimal communication and the gap between treatment and distribution of team job descriptions received by PNS and Non PNS officials is less or not proportional. Many of the workloads carried out are limited to aborting obligations and rarely reaching the essence of loyalty and worship. Limited interaction of team members so that there is less optimal communication and the gap between treatment and distribution of team job descriptions received by PNS and Non PNS officials is less or not proportional. Many of the workloads carried out are limited to aborting obligations and rarely reaching the essence of loyalty and worship.

Based on the background described above, the following problems can be formulated:

1. Does Team Trust have a significant effect on Team Cohesiveness of the employees of the Human Resources Development Agency of East Kalimantan Province?

2. Does Team Trust have a significant effect on Team Effectiveness among employees of the Human Resources Development Agency of East Kalimantan Province? 
International Journal of Economics, Business and Accounting Research (IJEBAR)

Peer Reviewed - International Journal

Vol-4, Issue-3, 2020 (IJEBAR)

E-ISSN: 2614-1280 P-ISSN 2622-4771

https://jurnal.stie-aas.ac.id/index.php/IJEBAR

3. Does Team Satisfaction have a significant effect on Team Cohesiveness for employees of the Human Resources Development Agency of East Kalimantan Province?

4. Does Team Satisfaction have a significant effect on Team Effectiveness for employees of the Human Resources Development Agency of East Kalimantan Province?

5. Does Team Satisfaction have a significant effect on Team Effectiveness for employees of the Human Resources Development Agency of East Kalimantan Province?

6. Can Team Cohesiveness mediate the relationship between Team Trust and Team Effectiveness among employees of the Human Resources Development Agency of East Kalimantan Province?

7. Whether Team Cohesiveness can mediate the relationship between Team Satisfaction and Team Effectiveness Effectiveness) on employees of the Human Resources Development Agency East Kalimantan Province?

\section{Research Method}

Research design refers to the overall strategy chosen to integrate the various components of the research in a logical way and to ensure the researcher will effectively design strategies for data collection, measurement and analysis. This study uses a quantitative-causal approach, which is to measure the causal effect on the relationship between the variables that have been hypothesized in the research model. Based on the time of data collection, this study uses a cross-sectional design that is data collection is carried out one time on the specified respondents. The research variable is a The attributes or characteristics of people, objects or activities that have certain variations are determined by researchers to study and draw conclusions, Sugiyono (2012). The definitions of the two variables are: 1 . Dependent variable (dependent variable) or dependent variable. That is the variable that is the main focus of the researcher. The essence of a problem is easily seen by recognizing the various dependent variables used in a model, Ferdinand (2013). In this study, the dependent variable is Team Cohesivity (Y1) and Team Effectiveness (Y2). 2. Independent variables (independent variables) or independent variables, namely variables that affect the dependent variable, whether the effect is positive or the effect is negative, Ferdinand (2013). Independent variables in this study: Team Trust (X1) and Team Satisfaction (X2) The essence of a problem is easily seen by recognizing the various dependent variables used in a model, Ferdinand (2013). In this study, the dependent variable is Team Cohesivity (Y1) and Team Effectiveness (Y2). 2. Independent variable (independent variable) or independent variable, namely the variable that affects the dependent variable, whether the effect is positive or the effect is negative, Ferdinand (2013). Independent variables in this study: Team Trust (X1) and Team Satisfaction (X2) The essence of a problem is easily seen by recognizing the various dependent variables used in a model, Ferdinand (2013). In this study, the dependent variable is Team Cohesivity (Y1) and Team Effectiveness (Y2). 2. Independent variables (independent variables) or independent variables, namely variables that affect the dependent variable, whether the effect is positive or the effect is negative, Ferdinand (2013). Independent variables in this study: Team Trust (X1) and Team Satisfaction (X2) Ferdinand (2013). Independent variables in this study: Team Trust (X1) and Team Satisfaction (X2) Ferdinand (2013). Independent variables in this study: Team Trust (X1) and Team Satisfaction (X2)

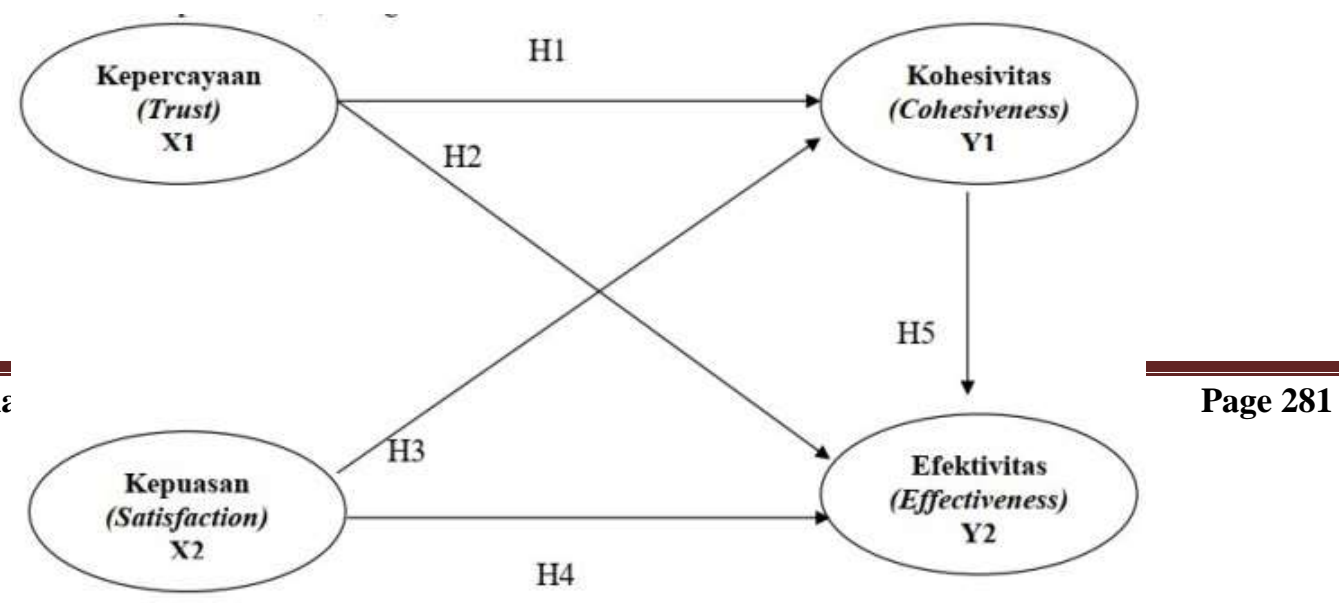


International Journal of Economics, Business and Accounting Research (IJEBAR)

Peer Reviewed - International Journal

Vol-4, Issue-3, 2020 (IJEBAR)

E-ISSN: 2614-1280 P-ISSN 2622-4771

https://jurnal.stie-aas.ac.id/index.php/IJEBAR

Based on background problems, theoretical studies, and previous research as well as the research concept framework above, the following hypothesis is proposed:

1. Trust (Trust) has a positive and significant effect on cohesiveness Team (Team Cohesiveness), (H1).

2. Team Trust has a positive and significant effect on Team Effectiveness, (H2).

3. Team Satisfaction has a positive and significant effect against Team Cohesiveness, (H3).

4. Team Satisfaction has a positive and significant effect on Team Effectiveness, (H4).

5. Team Cohesiveness has a positive and significant effect on Team Effectiveness, (H5).

6. Team cohesion (Team Cohesiviness) can mediate the relationship between Team Trust (Team Trust) on Effectiveness (Effectiviness), (H6).

7. Team cohesion (Team Cohesiviness) can mediate the relationship between Team Satisfaction on Team Effectiveness (Team Effectiviness), (H7).

\subsection{Data}

The data in this study used quantitative research data, namely data in the form of numbers or qualitative data which were assessed (scoring). Quantitative data were obtained from filling out a questionnaire measured by the Likert Type Item 5 option. In addition to questionnaires, some data such as internal reports in organizations and scientific journals are used as a basis for understanding problems and theoretical foundations for research. Population and sample of this research, Population is a generalization area consisting of objects / subjects that have certain qualities and characteristics determined by the researcher for study and then draw conclusions. Not all employees (PNS and Non PNS) in the Human Resources Development Agency of East Kalimantan Province can be the population in this study, because not all of them work in a team.

46 (forty six) people consisting of PNS and Non PNS, namely those who are included in the PKMF Field Team (Managerial and Functional Competency Development) and the PKT Field Team (Technical Competency Development). The sample is part of the total characteristics of the population, Sugiyono (2012). The sample in this study is the entire population (total sampling) with the consideration that it is not too difficult to obtain data because it is in one location. The sample in this study consisted of several (heterogeneous) elements, namely PNS and Non PNS Employees. The criteria used are grouping employees (PNS and Non PNS) who work in teams, namely: 1) PKMF (Managerial and Functional Competency Development) Team, totaling 25 (twenty five) people, and 2) PKT (Technical Competency Development) Team, totaling 21 (twenty one) people. The number of sample members is as follows:

Sample

\begin{tabular}{|ccc|}
\hline No. & Team Name & Total Member \\
\hline $\mathbf{1}$ & PKMF & 25 People \\
\hline $\mathbf{2}$ & PKT & 21 People \\
\hline
\end{tabular}

\subsection{Partial Least Square Analysis}

In this study, the data analysis used the partial least square (PLS) approach. Partial least square analysis (PLS) is a multivariate statistical technique that performs comparisons between multiple dependent variables and multiple independent variables. PLS is a variant-based SEM statistical method designed to solve multiple regression when specific problems occur in the data, such as small study sample size, 
International Journal of Economics, Business and Accounting Research (IJEBAR)

Peer Reviewed - International Journal

Vol-4, Issue-3, 2020 (IJEBAR)

E-ISSN: 2614-1280 P-ISSN 2622-4771

https://jurnal.stie-aas.ac.id/index.php/IJEBAR

missing data and multicollinearity, Jogiyanto (2011). According to Ghozali \& Latan (2014), PLS is an alternative approach that shifts from a covariance-based to variant-based SEM approach. Covariancebased SEM generally tests causality / theory while PLS is more of a predictive model. PLS is a powerful analytical method Ghozali \& Latan (2014), because it is not based on many assumptions. For example, the data must be normally distributed, the sample does not have to be large. Besides being able to be used to confirm the theory, PLS can also be used to explain whether there is a relationship between latent variables. PLS can simultaneously analyze the constructs formed by reflective and formative indicators. According to Ghozali \& Latan (2014), the purpose of PLS is to help researchers for predictive purposes. The formal model defines latent variables as linear aggregates of the indicators.

The weight estimate for creating a latent variable score component is obtained based on how the inner model (a structural model that connects between latent variables) and the outer model (the measurement model, which is the relationship between the indicator and its construct) is specified. The result is the residual variance of the dependent variable. The parameter estimates obtained by PLS can be categorized into three. First, is the weight estimate used to create the latent variable score. Second, it reflects the path estimate that connects latent variables and between latent variables and their indicators (loading). Third, it relates to means and location parameters (regression constant values) for indicators and latent variables. To obtain these three estimates, PLS uses a 3-stage iteration process and each iteration stage produces an estimate. The first stage is to produce a weight estimate, the second stage is to generate an estimate for the inner model and outer model, and the third stage to produce an estimate of means and location, Ghozali \& Latan (2014).

The parameter estimates obtained by PLS can be categorized into three. First, is the weight estimate used to create the latent variable score. Second, it reflects the path estimate that connects latent variables and between latent variables and their indicators (loading). Third, it relates to the means and location parameters (regression constant values) for indicators and latent variables. To obtain these three estimates, PLS uses a 3-stage iteration process and each iteration stage produces an estimate. The first stage is to produce a weight estimate, the second stage is to produce an estimate for the inner model and outer model, and the third stage to produce an estimate of means and location, Ghozali \& Latan (2014). The parameter estimates obtained by PLS can be categorized into three. First, is the weight estimate used to create the latent variable score. Second, it reflects the path estimate that connects latent variables and between latent variables and their indicators (loading).

Third, it relates to the means and location parameters (regression constant values) for indicators and latent variables. To obtain these three estimates, PLS uses a 3 -stage iteration process and each iteration stage produces an estimate. The first stage is to produce a weight estimate, the second stage is to produce an estimate for the inner model and outer model, and the third stage to produce an estimate of means and location, Ghozali \& Latan (2014). Second, it reflects the path estimate that connects latent variables and between latent variables and their indicators (loading). Third, it relates to means and location parameters (regression constant values) for indicators and latent variables. To obtain these three estimates, PLS uses a 3-stage iteration process and each iteration stage produces an estimate. The first stage is to produce a weight estimate, the second stage is to produce an estimate for the inner model and outer model, and the third stage to produce an estimate of means and location, Ghozali \& Latan (2014). Second, it reflects the path estimate that connects latent variables and between latent variables and their indicators (loading). Third, it relates to means and location parameters (regression constant values) for indicators and latent variables.

To obtain these three estimates, PLS uses a 3-stage iteration process and each iteration stage produces an estimate. The first stage is to produce a weight estimate, the second stage is to produce an estimate for the inner model and outer model, and the third stage to produce an estimate of means and location, Ghozali \& Latan (2014). To obtain these three estimates, PLS uses a 3-stage iteration process and each iteration stage produces an estimate. The first stage is to produce a weight estimate, the second stage is to produce an estimate for the inner model and outer model, and the third stage to produce an 
International Journal of Economics, Business and Accounting Research (IJEBAR)

Peer Reviewed - International Journal

Vol-4, Issue-3, 2020 (IJEBAR)

E-ISSN: 2614-1280 P-ISSN 2622-4771

https://jurnal.stie-aas.ac.id/index.php/IJEBAR

estimate of means and location, Ghozali \& Latan (2014). To obtain these three estimates, PLS uses a 3 stage iteration process and each iteration stage produces an estimate. The first stage is to produce a weight estimate, the second stage is to produce an estimate for the inner model and outer model, and the third stage to produce an estimate of means and location, Ghozali \& Latan (2014).

\section{Results and Discussion}

\subsection{Results}

Response based on ASN status

\begin{tabular}{|ccc|}
\hline Status & Total & Percentage $\%$ \\
\hline Civil servants & 30 & $65 \%$ \\
\hline PPPK & 16 & $35 \%$ \\
\hline Total & 46 & $100 \%$ \\
\hline
\end{tabular}

Response based on Gender

\begin{tabular}{|ccc|}
\hline Gender & Total & Percentage\% \\
\hline Man & 21 & $46 \%$ \\
\hline Woman & 25 & $54 \%$ \\
\hline Total & 46 & $100 \%$ \\
\hline
\end{tabular}

Responses based on education level

\begin{tabular}{|ccc|}
\hline Education Level & Total & Percentage $\%$ \\
\hline High school & 9 & $20 \%$ \\
\hline D3 & 10 & $22 \%$ \\
\hline S1 & 15 & $33 \%$ \\
\hline S2 & 12 & $26 \%$ \\
\hline Total & 46 & 100 \\
\hline
\end{tabular}

Cross Loadings Test Results

\begin{tabular}{|c|c|c|c|c|}
\hline Indicator & CH & EF & SF & TR \\
\hline CH1 & $\mathbf{0 . 5 7 3}$ & 0.529 & 0.695 & 0.297 \\
\hline CH2 & $\mathbf{0 . 8 7 6}$ & 0.796 & 0.599 & 0.719 \\
\hline CH3 & $\mathbf{0 . 8 5 3}$ & 0.701 & 0.617 & 0.714 \\
\hline CH4 & $\mathbf{0 . 8 7 4}$ & 0.693 & 0.589 & 0.666 \\
\hline CH5 & $\mathbf{0 . 6 7 7}$ & 0.585 & 0.423 & 0.316 \\
\hline EF1 & 0.855 & $\mathbf{0 . 8 5 5}$ & 0.676 & 0.557 \\
\hline EF2 & 0.460 & $\mathbf{0 . 6 7 6}$ & 0.330 & 0.528 \\
\hline EF3 & 0.427 & $\mathbf{0 . 6 3 4}$ & 0.517 & 0.264 \\
\hline SF1 & 0.395 & 0.427 & $\mathbf{0 . 7 7 0}$ & 0.568 \\
\hline SF2 & 0.564 & 0.558 & $\mathbf{0 . 7 3 7}$ & 0.714 \\
\hline SF3 & 0.659 & 0.584 & $\mathbf{0 . 7 2 5}$ & 0.752 \\
\hline
\end{tabular}


International Journal of Economics, Business and Accounting Research (IJEBAR)

Peer Reviewed - International Journal

Vol-4, Issue-3, 2020 (IJEBAR)

E-ISSN: 2614-1280 P-ISSN 2622-4771

https://jurnal.stie-aas.ac.id/index.php/IJEBAR

\begin{tabular}{|c|c|c|c|c|}
\hline SF4 & 0.458 & 0.481 & $\mathbf{0 . 6 3 0}$ & 0.134 \\
\hline SF5 & 0.413 & 0.400 & $\mathbf{0 . 5 5 0}$ & -0.029 \\
\hline TR1 & 0.689 & 0.621 & 0.536 & $\mathbf{0 . 8 7 0}$ \\
\hline TR2 & 0.619 & 0.448 & 0.516 & $\mathbf{0 . 9 1 0}$ \\
\hline TR3 & 0.553 & 0.533 & 0.708 & $\mathbf{0 . 8 0 2}$ \\
\hline
\end{tabular}

Source: Results of data processing, 2020

AVE and AVE Root

\begin{tabular}{|c|c|c|c|}
\hline Variable & AVE & AVE root & Ket \\
\hline CH & 0.884 & 0.610 & Valid \\
\hline EF & 0.769 & 0.530 & Valid \\
\hline SF & 0.815 & 0.472 & NotValid \\
\hline TR & 0.896 & 0.742 & Valid \\
\hline
\end{tabular}

Source: Results of data processing, 2020

$\mathrm{R}$ coefficient 2

\begin{tabular}{|c|c|}
\hline R Square & \\
\hline CH & 0.648 \\
\hline EF & 0.751 \\
\hline
\end{tabular}

Source: Results of data processing, 2020

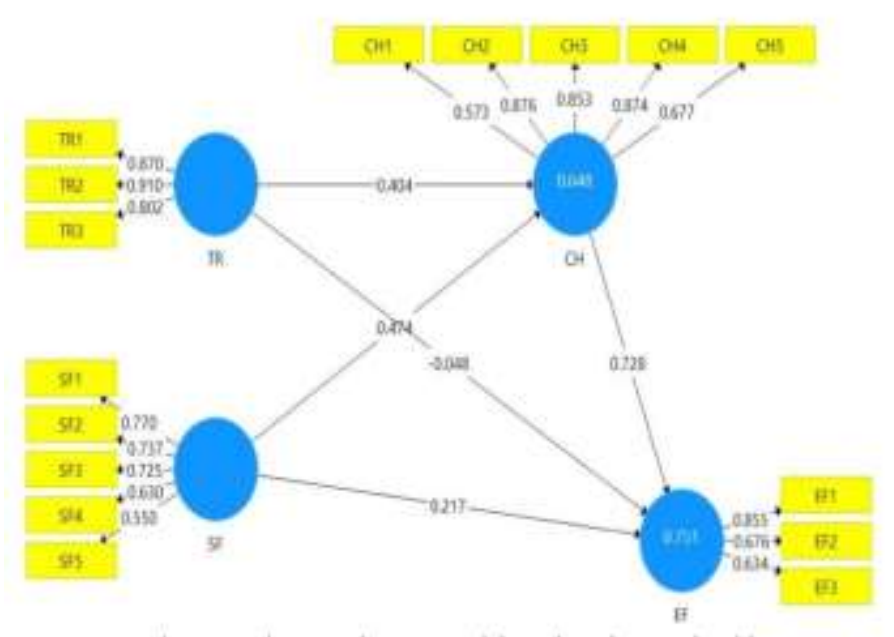

PLS Algorithm Structural Model Path Diagram

Source: Results of Data Processing, 2020 


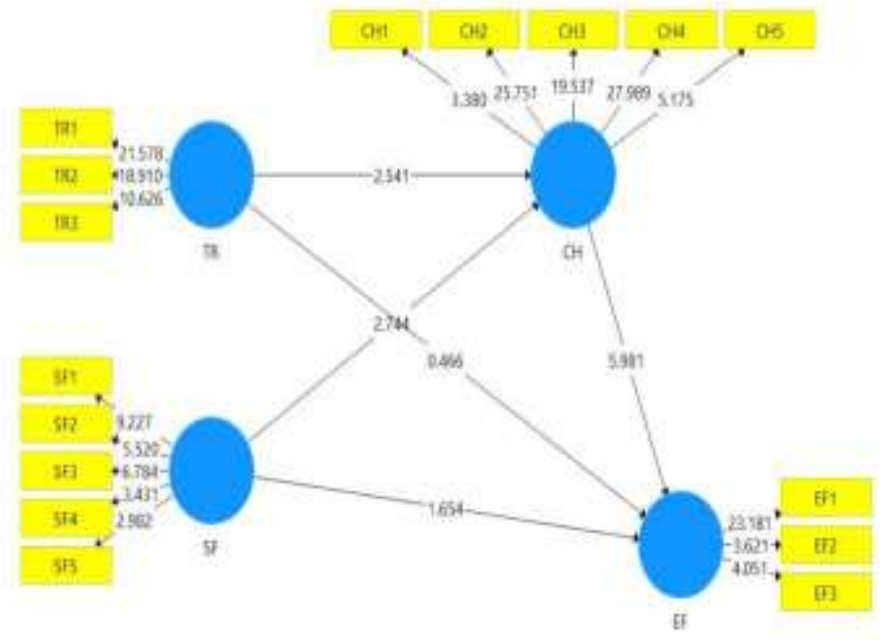

PLS Bootstrapping Structural Model Path Diagram

Source: Results of Data Processing, 2020

\subsection{Discussion}

\section{The Effect of Team Trust on Team Cohesivity (Team Cohesiveness)}

Based on the results of the analysis and hypothesis testing, it is concluded that trust has a positive and significant effect on cohesiveness. This positive coefficient value indicates that the better the trust, the betterThis implies better cohesiveness in the Human Resources Development Agency of East Kalimantan Province.

To maintain and increase Team Trust in order to increase Team Cohesivity, a number of things can be done, including, among others, by providing good examples / examples from leaders or senior employees, increasing care / empathy for fellow employees. and increase the active participation of all members / employees.

\section{The Effect of Team Trust on Team Effectiveness)}

Based on the results of analysis and hypothesis testing, it is concluded that Trust is not significant to Effectiveness This coefficient value indicates that good or bad trust has a less dominant influence on the effectiveness of the Human Resources Development Agency of East Kalimantan Province. There are things that can be done to maintain and maintain Team Trust in order to increase Team Effectiveness, including through the need to increase good and intensive relationships between superiors and subordinates as well as fellow colleagues as well as implementing good conflict management (immediately overcoming problems so that they do not prolong and raises new problems).

\section{Effect of Team Satisfaction on Team Cohesivity (Team Cohesiveness)}

Based on the results of the analysis and hypothesis testing, it is concluded that satisfaction is proven to have a positive and significant effect on cohesiveness. This positive coefficient value indicates that the better the satisfaction, the better This implies better cohesiveness in the Human Resources Development Agency of East Kalimantan Province. employee ideas and always provide motivation to employees. 
International Journal of Economics, Business and Accounting Research (IJEBAR)

Peer Reviewed - International Journal

Vol-4, Issue-3, 2020 (IJEBAR)

E-ISSN: 2614-1280 P-ISSN 2622-4771

https://jurnal.stie-aas.ac.id/index.php/IJEBAR

\section{Effect of Team Satisfaction on Team Effectiveness (Team Effectiveness)}

Based on the results of the analysis and hypothesis testing, it is concluded that satisfaction does not have a significant effect on effectiveness. This coefficient value indicates that good or bad satisfaction does not affect the effectiveness of the Human Resources Development Agency of East Kalimantan Province.

Things that can be done to increase member satisfaction in order to improve organizational work effectiveness include refresher (rolling / transfer of staff) to the work environment and placing employees in a position based on their respective competencies and passions, developing employee competencies (through training, coaching, mentoring and others), adding adequate work support facilities (equipment and applications) so that the goals and team effectiveness can be achieved as expected.

\section{The Effect of Team Cohesiveness on Team Effectiveness}

Based on the results of analysis and hypothesis testing, Cohesivity is proven to have a positive and significant effect on effectiveness. This positive coefficient value indicates that the better the cohesiveness, it will have implications for the better the effectiveness of the Human Resources Development Agency of East Kalimantan Province.

To increase Team Cohesiveness so that Team Effectiveness can also increase, an institution can make efforts, among others, by continuously disseminating the vision, mission and goals of the organization to all employees (PNS and Non PNS) so that all parties have the same understanding of the direction and goals of the organization and improve relations between employees in both official and non-official / informal relationships, for example through routine / periodic meetings (staff meetings, coffee mornings, outbound and others).

\section{The Effect of Team Trust on Team Effectiveness through Team Cohesiveness}

Based on the results of the analysis and hypothesis testing, it is concluded that the effect of trust on effectiveness through cohesiveness has a positive and significant effect. This means that the Cohesivity variable can mediate Trust in Effectiveness, in the Human Resources Development Agency of East Kalimantan Province.

Things that can be done to maintain and increase Team Trust and Team Cohesiveness in order to increase Team Effectiveness include implementing an open communication system between all parties, building a strong commitment from all organizational components and applying the principle of transparency within the organization.

\section{The Effect of Team Satisfaction on Team Effectiveness through Team Cohesiveness}

Based on the results of the analysis and hypothesis testing, it is concluded that the effect of satisfaction on effectiveness through cohesiveness has a positive and significant effect. This means that the Cohesivity variable can mediate satisfaction with effectiveness at the Human Resources Development Agency of East Kalimantan Province.

Things that can be done to maintain and increase Team Satisfaction and Team Cohesiveness in order to increase Team Effectiveness, among others, by implementing a fair reward and punishment system and the existence of a leader who is wise and has high integrity, considering that in BPSDM East Kalimantan Province in a period of more than The last 1 (one) year has no definitive leadership.

\section{Conclusion}

1. Trust has a positive and significant effect on cohesiveness. This explains that the better trust is, it will have implications for better cohesiveness in the Human Resources Development Agency of East Kalimantan Province. 
International Journal of Economics, Business and Accounting Research (IJEBAR)

Peer Reviewed - International Journal

Vol-4, Issue-3, 2020 (IJEBAR)

E-ISSN: 2614-1280 P-ISSN 2622-4771

https://jurnal.stie-aas.ac.id/index.php/IJEBAR

2. Trust is not significant towards Effectiveness. The results of the study explained that the high and low number of trust had no effect on the effectiveness of the Human Resources Development Agency of East Kalimantan Province.

3. Satisfaction has a positive and significant effect on cohesiveness. And it can be concluded that the better the satisfaction, it will have implications for the better cohesiveness of the Human Resources Development Agency of East Kalimantan Province.

4. Satisfaction is not significant to Effectiveness. From the research results it can be explained that good or bad the Satisfaction number does not affect the effectiveness of the Human Resources Development Agency of East Kalimantan Province.

5. Cohesivity has a positive and significant effect on effectiveness. The results showed that the better the cohesiveness, the better the effectiveness of the Human Resources Development Agency of East Kalimantan Province.

6. Belief in effectiveness through cohesiveness has a positive and significant effect. This means that the Cohesivity variable can mediate Trust in Effectiveness in the Human Resources Development Agency of East Kalimantan Province.

7. Satisfaction with effectiveness through cohesiveness has a positive and significant effect. In other words, Cohesiveness can mediate Satisfaction with Effectiveness at the Provincial Human Resource Development Agency East Kalimantan.

\section{Reference}

Alsharo, M., Gregg, D., \& Ramirez, R. (2017). Virtual team effectiveness: The role of knowledge sharing and trust. Information and Management, 54 (4), 479-490. https://doi.org/10.1016/j.im.2016.10.005

Anisa, FN, Gayatri, S., \& Dalmiyatun, T. (2020). The Effect of Members 'Trust on the Cohesiveness of Sumber Rejeki Farmers' Group, Purwosari Village, Mijen District, Semarang City. Agrisocionomics: Journal of Agricultural Socio-Economics, 4 (1), 176-191.

Aoyagi, MW, Cox, RH, \& McGuire, RT (2008). Organizational citizenship behavior in sport: Relationships with leadership, team cohesion, and athlete satisfaction. Journal of Applied Sport Psychology, 20 (1), 25-41. https://doi.org/10.1080/10413200701784858

Arikunto, S. (2013). Research Management (12th ed.). Rineka Cipta.

Barker, C., Pistrang, N., \& Elliott, R. (2015). Research Methods in Clinical Psychology: An Introduction for Students and Practitioners, 3rd Edition. Wiley-Blackwell.

Benrazavi, Seyed Rahim; Silong, AD (2013). Employees' Job Satisfaction and Its Influence on Willingness to Work in Teams Universiti Putra Malaysia. Journal of Management Policy and Practice, 14 (2004), 127-141.

Bravo, R., Catalán, S., \& Pina, JM (2018). Analyzing teamwork in higher education: an empirical study on the antecedents and consequences of team cohesiveness. Studies in Higher Education, 1-13. https://doi.org/10.1080/03075079.2017.1420049

Carron, AV, Widmeyer, WN, \& Brawley, LR (1985). The Development of an Instrument to Assess Cohesion in Sport Teams: The Group Environment

Questionnaire. Journal of Sport Psychology. https://doi.org/10.1123/jsp.7.3.244

Chen, CC, \& Chiu, SF (2009). The mediating role of job involvement in the relationship between job characteristics and organizational citizenship behavior. Journal of Social Psychology, 149 (4), 474-494. https://doi.org/10.3200/SOCP.149.4.474-494

Costa, AC, Fulmer, CA, \& Anderson, NR (2018). Trust in work teams: An integrative review, multilevel model, and future directions. Journal of Organizational Behavior, 39 (2), 169-184. https://doi.org/10.1002/job.2213 
International Journal of Economics, Business and Accounting Research (IJEBAR)

Peer Reviewed - International Journal

Vol-4, Issue-3, 2020 (IJEBAR)

E-ISSN: 2614-1280 P-ISSN 2622-4771

https://jurnal.stie-aas.ac.id/index.php/IJEBAR

Daspit, J., Tillman, CJ, Boyd, NG, \& Mckee, V. (2013). Cross-functional team effectiveness: An examination of internal team environment, shared leadership, and cohesion influences. Team Performance Management, 19 (1), 34-56. https://doi.org/10.1108/13527591311312088

DeOrtentiis, PS, Summers, JK, Ammeter, AP, Douglas, C., \& Ferris, GR (2013). Cohesion and satisfaction as mediators of the team trust - team effectiveness relationship: An interdependence theory perspective. Career Development International, 18 (5), 521-543. https://doi.org/10.1108/CDI-03-2013-0035

Durneac, CP (2012). Group cohesion and performance a bank analysis. Acta Universitatis Danubius: Oeconomica, 8 (4), 32-40.

Ferdinand, A. (2006). Management Research Methods: Research Guidelines for Thesis, Thesis and Management Science Accompanied.

Festinger, L., Back, K., Hymovitch, B., Kelley, H., Schachter, S., \& Thibaut, J. (1950). A method of studying rumor transmission. Journal of Chemical Information and Modeling. https://doi.org/10.1017/CBO9781107415324.004

Fung, H. (2014). Relationships Among Team Trust, Team Cohesion, Team Satisfaction and Project Team Effectiveness as Perceived by Project Managers in Malaysia. Relationships among Team Trust, Team Cohesion, Team Satisfaction and Project Team Effectiveness as Perceived by Project Managers in Malaysia, 1 (1), 1-15.

Ghozali, I., \& Latan, H. (2014). Partial Least Square: Concepts, Methods \& Applications Using the WARPPLS 4.0 Program (2nd ed.). Undip.

Hair, JF, Ringle, CM, \& Sarstedt, M. (2011). PLS-SEM: Indeed a Silver Bullet. Journal of Marketing Theory and Practice, 19 (2), 139-152. https://doi.org/10.2753/MTP1069-6679190202

Jogiyanto. (2011). Business Research Methodology (BPFE-YOGYAKARTA (ed.); 4th ed.). BPFEYOGYAKARTA.

Kreitner, R., \& Kinichi, A. (2014). Organizational behavioral-Ed. 5. (H. McGraw (ed.)).

$\mathrm{Ku}, \mathrm{HY}$, Tseng, HW, \& Akarasriworn, C. (2013). Collaboration factors, teamwork satisfaction, and student attitudes toward online collaborative learning. Computers in Human Behavior, 29 (3), 922-929. https://doi.org/10.1016/j.chb.2012.12.019

Langton, N., Robbins, SP, \& Judge, TA (2014). Organizational Behavior: Concept. Controversies, Applications. In Organizational Behavior. https://doi.org/10.1007/978-1-137-31243-3_1

Larasati, RD, Pandjaitan, NK, \& Hermawan, A. (2017). The influence of cohesiveness and job satisfaction on organizational Citizenship Behavior at PT Agricon. Journal of Management and Organization, 8 (2), 157-172.

Li, A., \& Thatcher, SMB (2015). Understanding the Effects of Self and Teammate OCB Congruence and Incongruence. Journal of Business and Psychology, 30 (4), 641-655. https://doi.org/10.1007/s10869-014-9387-0

Mcshane, SL, \& Glinow, MA Von. (2018). Organizational Behavior 8.

Mulyatiningsih, E. (2012). Method Research Applied Field Education.

ALFABETA CV.

Noor, J. (2011). Research Methodology: Thesis, Thesis, Dissertation, \& Scientific Work. prenada media group.

Onağ, Z., \& Tepeci, M. (2014). Team Effectiveness in Sport Teams: The Effects of Team Cohesion, Intra Team Communication and Team Norms on Team Member Satisfaction and Intent to Remain. Procedia - Social and Behavioral Sciences, 150, 420-428. https://doi.org/10.1016/j.sbspro.2014.09.042

Paul, R., Drake, JR, \& Liang, H. (2016). Global Virtual Team Performance: The Effect of Coordination Effectiveness, Trust, and Team Cohesion. IEEE Transactions on Professional Communication, 59 (3), 186-202. https://doi.org/10.1109/TPC.2016.2583319 
International Journal of Economics, Business and Accounting Research (IJEBAR)

Peer Reviewed - International Journal

Vol-4, Issue-3, 2020 (IJEBAR)

E-ISSN: 2614-1280 P-ISSN 2622-4771

https://jurnal.stie-aas.ac.id/index.php/IJEBAR

Picazo, C., Gamero, N., Zornoza, A., \& Peiró, JM (2015). Testing relations between group cohesion and satisfaction in project teams: A cross-level and cross-lagged approach. European Journal of Work and Organizational Psychology, 24 (2), 297-307. https://doi.org/10.1080/1359432X.2014.894979

Pramlal, A. (2004). The Influence Of Team Cohesiveness On Team Effectiveness Ashika Pramlal Submitted in Partial fulfillment of the Requirements for the Degree of Masters in Administration (Human Resource Management) In the School of Human Resource Management In the Facult. March.

Salas, E., Grossman, R., Hughes, AM, \& Coultas, CW (2015). Measuring team cohesion: Observations from the science. Human Factors, 57 (3), 365- 374. https://doi.org/10.1177/0018720815578267

Schermerhorn, JR, Hunt, JG, \& Osborn, RN (2010). Organizational Behavior (7th ed.).

Shujaat, S., Manzoor, A., \& Syed, NA (2014). (PDF) Impact of Team Work on Employee Satisfaction. Journal of Management \& Social Sciences, 10 (2), 71-80.

Sugiyono. (2012). Sugiyono's Educational Research Methods Book Download Sugiyono's Educational Research Methods Book.

Umar, H. (2011). Research Methods for Thesis and Business Thesis (2nd Edition). press eagle.

Urien, B., Osca, A., \& García-Salmones, L. (2017). Ambigüedad de rol, cohesión grupal y satisfacción laboral: un estudio con el modelo demandas y recursos laborales (JD-R) en México y España. Revista Latinoamericana de Psicologia, 49 (2), 137-145. https://doi.org/10.1016/j.rlp.2015.09.014

Zheng, W., Zhang, M., \& Li, H. (2012). Performance appraisal process and organizational citizenship behavior. Journal of Managerial Psychology, 27 (7), 732-752. https://doi.org/10.1108/02683941211259548 